\title{
Article
}

\section{Systematic Review and Meta-Analysis of Psychosocial Risk Factors for Stroke}

Lightbody, Catherine Elizabeth, Clegg, Andrew, Patel, Kulsum, Cook Lucas, Julie, Storey, Hannah, Hackett, Maree and Watkins, Caroline Leigh

Available at http://clok.uclan.ac.uk/19495/

Lightbody, Catherine Elizabeth ORCID: 0000-0001-5016-3471, Clegg, Andrew ORCID: 0000-0001-8938-7819, Patel, Kulsum, Cook Lucas, Julie ORCID: 00000002-6391-5430, Storey, Hannah ORCID: 0000-0002-1250-8368, Hackett, Maree ORCID: 0000-0003-1211-9087 and Watkins, Caroline Leigh ORCID: 0000-0002-9403-3772 (2017) Systematic Review and Meta-Analysis of Psychosocial Risk Factors for Stroke. Seminars in Neurology, 37 (03). pp. 294306. ISSN 0271-8235

It is advisable to refer to the publisher's version if you intend to cite from the work. http://dx.doi.org/10.1055/s-0037-1603758

For more information about UCLan's research in this area go to http://www.uclan.ac.uk/researchgroups/ and search for <name of research Group>.

For information about Research generally at UCLan please go to http://www.uclan.ac.uk/research/

All outputs in CLoK are protected by Intellectual Property Rights law, including Copyright law. Copyright, IPR and Moral Rights for the works on this site are retained by the individual authors and/or other copyright owners. Terms and conditions for use of this material are defined in the policies page.

\section{CLoK}

Central Lancashire online Knowledge www.clok.uclan.ac.uk

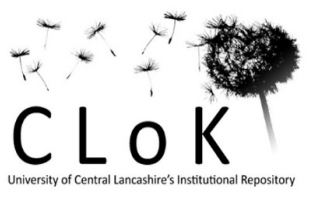


Title

Systematic Review and Meta-analysis of Psychosocial Risk Factors for Stroke

\section{Author details}

Dr. C. Elizabeth Lightbody, PhD, MPhil, BN (Hons), Reader in Health Services Research, School of Nursing Brook 415, Preston PR1 2HE, Tel:+44 01772893648, Email: celightbody@uclan.ac.uk

Professor Andrew Clegg, BA (Hons), MSc, PhD, Professor of Health Services Research, Faculty of Health and Wellbeing, University of Central Lancashire, Brook 419

Preston PR1 2HE, Tel: :+44 01772895545, Email: AClegg3@uclan.ac.uk

Kulsum Patel, BSc (Hons), Senior Research Assistant, School of Nursing, University of Central Lancashire, Tel:+44 01772893635, Email: KPatel@uclan.ac.uk

Julie M Lucas, Julie Cook Lucas, BA (Hons), Research Associate, Research Support Team, Faculty of Healt Central Lancashire, Brook 425, Preston PR1 2HE, Tel:+44 01772892549, Email: JMLucas@uclan.ac.uk 
Hannah Storey, BSc (Hons), MSc, Research Assistant, Research Support Team, Faculty of Health and Wellbeing, University of Central Lancashire, Brook 425, Preston PR1 2HE Tel:+44 01772896322. Email: HStorey2@uclan.ac.uk

Professor Maree L Hackett, Ph.D., M.A. (Hons), B.A. Professor of Epidemiology, School of Nursing, University of Central Lancashire, \& Acting Director, Neurological and Mental Health Division, The George Institute for Global Health, University of New South Wales, Sydney, Australia. Email: mhackett@georgeinstitute.org.au

Professor Dame Caroline L Watkins, DBE, FESO, PhD, RN, Professor of Stroke \& Older People’s Care / Faculty Director of Research and Innovation, Faculty of Health and Wellbeing, University of Central Lancashire, Professorial Fellow in Stroke Care, Faculty of Health Sciences, Australian Catholic University, Tel: +44 (0) 1772893646

Email: clwatkins@uclan.ac.uk

Corresponding author

Dr C. Elizabeth Lightbody

PhD, MPhil, BN (Hons)

Reader in Health Services Research

School of Nursing

University of Central Lancashire

Brook 415

Preston PR1 2HE

celightbody@uclan.ac.uk 
+4401772893648 


\begin{abstract}
Background

Several studies have assessed the link between psychosocial risk factors and stroke; however, the results are inconsistent. We have conducted a systemic review and meta-analysis of cohort or case-control studies to ascertain the association between psychosocial risk factors (psychological, vocational, behavioral, interpersonal and neuropsychological) and the risk of stroke.
\end{abstract}

\title{
Methods
}

Systematic searches were undertaken in MEDLINE, EMBASE, CINAHL, PsycInfo and the Cochrane Database of Systematic Reviews between 2000 and January 2017. Two reviewers independently screened titles, abstracts and full texts. One reviewer assessed quality and extracted data, which was checked by a second reviewer. For studies that reported risk estimates, a meta-analysis was performed.

\section{Results}

We identified 41 cohort studies and five case-control studies. No neuropsychological papers were found. Overall pooled adjusted estimates showed that all other psychosocial risk factors were independent risk factors for stroke. Psychological factors increased the risk of stroke by 39\% (HR 1.39 95\% CI:1.27;1.51), vocational by 35\% (HR 1.35 95\% CI: 1.20;1.51), and interpersonal by 16\% (HR 1.16 95\% CI:1.03;1.31). and the effects of behavioral factors were equivocal (HR 0.94 95\% CI: 0.20;4.31). The meta-analyses were affected by heterogeneity.

\section{Conclusions}

Psychosocial risk factors are associated with an increased risk of stroke

\section{Key words (3 to 5)}

Stroke, psychosocial, risk factor 


\section{Background}

Stroke and heart disease are leading causes of death, and stroke is a major cause of complex disability globally ${ }^{1}$. Identification of modifiable risk factors for stroke over and above known risk factors for chronic disease may provide more targets for stroke prevention. With increasing evidence that psychosocial factors increase the risk of cardiovascular disease generally, ${ }^{2}$ there is a need to elucidate whether specific psychosocial factors increase the risk of stroke and transient ischaemic attack (TIA).

Several meta-analyses have shown that some psychosocial risk factors increase the risk of stroke. A recent systematic review and meta-analysis consisting of 14 studies found a 33\% increase in the risk of stroke incidence for those with perceived psychosocial stress ${ }^{3}$. Another meta-analysis indicated that depression significantly increases the risk of stroke, and this increase may have been independent of other risk factors, including hypertension and diabetes ${ }^{4}$.

Single studies have shown that apathy rather than depression has the stronger association with stroke ${ }^{5}$, and another showed that lower life satisfaction is associated with an increased risk of stroke, especially in women ${ }^{6}$. Furthermore, depression is associated with other psychosocial risk factors such as reduced social support, which, in turn, have been associated with stroke ${ }^{7}$ and atherogenesis ${ }^{8}$.

The mechanisms of action between psychosocial risk factors and stroke are not fully understood but are likely to be multifaceted and include lifestyle factors (e.g., poor diet, smoking, alcohol use, and low physical activity) and physiological components (e.g., hypertension, diabetes mellitus, obesity, and inflammation), which may be mediated by psychological factors (e.g., depression, anxiety, loneliness, self-efficacy). 
We conducted a systematic review and meta-analysis to explore the specific contribution of a variety of psychosocial risk factors to the risk of stroke and TIA. We used the broad categories of psychological (e.g. depression, anxiety, mood, stress, distress, life satisfaction, resilience, self-efficacy, self-esteem, schizophrenia), vocational (e.g. employment, work, job satisfaction, education, finance, poverty), behavioral (e.g. coping, challenging behavior, anger), interpersonal (e.g. emotional support, social support, isolation, life changing events, loneliness, quality of life, social activity, leisure) and neuropsychological (e.g. language, aphasia, memory, visuospatial, executive function) to summarize our findings.

\section{Search strategy}

Systematic searches of published papers indexed in MEDLINE, EMBASE, CINAHL, PsycInfo and Cochrane Database of Systematic Reviews between 2000 and January 2017 were undertaken using a strategy combining selected subject headings and keywords relating to psychosocial risk factors and stroke. The search strategy was developed for use in Medline and amended for use in other databases. Manual searching of relevant systematic reviews and the reference lists of included studies was also performed. Only English language studies were included.

\section{Study selection}

Two reviewers (from AC, CEL, JL, KP, HS) independently screened titles and abstracts, where available, of bibliographic records retrieved. Full text copies of potentially relevant studies were retrieved and assessed by two reviewers (from CEL, JL, KP, HS). Study selection was undertaken using predetermined selection criteria to assess eligibility. Studies were included in the meta-analysis if they met all the following criteria: (1) cohort or casecontrol design; (2) exposure to one or more psychosocial factors, including psychological, vocational, behavioral, interpersonal, and neuropsychological; (3) use of adjusted models or 
matching procedures that controlled for at least one potential confounder; (4) reported risk estimates for stroke outcomes with 95\% CI comparing participants who had experienced exposure to psychosocial risk factors to participants who had not experienced exposure to psychosocial risk factors, or who had experienced psychosocial risk factors to a lesser degree; and (5) study population consisted of only those without prior stroke at baseline (for cohort studies). A broad definition of stroke was adopted to include ischemic stroke, hemorrhagic stroke, subarachnoid hemorrhage and TIA. Studies were excluded if: (1) they reported only fatal strokes without reporting total incidence of stroke occurrence; (2) stroke occurrence was based only on self report without confirmation using medical records; (3) cognition/memory was the risk factor under study without any other psychosocial factor; (4) a composite construct of psychological distress was used (unless a measure of psychosocial stress could be extracted); or (5) there were fewer than 20 participants. Disagreements were resolved through discussion, with recourse to a third reviewer where necessary.

\section{Data extraction and quality appraisal}

One reviewer (from MLH, CEL, JL, KP, HS, AC) extracted data using a review-specific data extraction tool. Data to be extracted included details of study aim, study design and methods, study population including age and sex, psychosocial risk factors under investigation, stroke outcomes and measurement or confirmation method, number and type of confounders adjusted for, study limitations and conclusions. Methodological quality was assessed using the NIH Quality Assessment Tool for Observational Cohort and Cross-Sectional Studies ${ }^{9}$. A second reviewer (from CEL, JL, KP, HS, AC) checked extracted data and quality assessment. Disagreements were resolved through discussion, with recourse to a third reviewer where necessary.

\section{Data synthesis}


Studies were synthesized through a narrative review with tabulation of the outcomes from the included studies. Studies were classified into five groups: psychological, behavioral, vocational, interpersonal and neuropsychological. Outcomes selected for synthesis were based on those available for all persons, all types of stroke and those considered to characterise the type of psychosocial risk factor most accurately, and were made by consensus. Where studies presented outcomes only by sub-groups, whether by population or type of stroke, these were included in the analysis and identified. For studies reporting risk estimates, a meta-analysis was performed to pool estimates of association. Random effects models were estimated given the likelihood of heterogeneity. Hazard ratios (HRs) were used as the common risk estimate for cohort studies (relative risks (RR) were considered equivalent to $\mathrm{HR})^{3}$, and odds ratios (ORs) for case-control studies. Where cohort or casecontrol studies reported a different risk estimate (i.e. cohort studies presenting ORs or RR and case-control studies HR), a series of sensitivity and sub-group analyses were undertaken based on pooling by the type of risk estimates and/or study designs. Other sensitivity analyses assessed the effects of specific outlying studies. If different adjusted risk estimates were reported, the most fully adjusted estimate was included. Heterogeneity was assessed through visual inspection of Forest plots and the use of $\mathrm{I}^{2}$ statistics following recognised guidance regarding interpretation. ${ }^{10}$ Publication bias was assessed using funnel plots. Meta-analyses were undertaken in Cochrane Collaboration Review Manager (version 5.3).

\section{Results}

\section{Study Characteristics}

We identified 4889 citations, of which 46 were included in the meta-analysis (Fig.1). Thirty studies examined the impact of psychological factors, 13 vocational factors, 2 behavioral factors, and 10 interpersonal factors on risk of stroke. No studies assessed neuropsychological factors. The characteristics of the cohort and case control studies are presented in Tables 1 
and 2, respectively. Participants ranged in age at study baseline from $18^{11}$ to $100^{12}$ years. Although most studies contained proportions of men and women between $40 \%$ to $60 \%{ }^{6,11,12,13-41}$, eight cohort studies focused exclusively on men or women ${ }^{42-49}$. The cohort sizes ranged from 25 to 4718 participants ${ }^{20,50}$, while the case-control studies ranged in size from 346 to $26,949^{41,51}$. Length of follow-up ranged from 1 day to 35 years ${ }^{11,31}$. Although studies encompassed several risk factors in their analyses, only a subset considered comparable are presented in these analyses. All cohort studies and 3 case-control studies included participants with fatal and non-fatal strokes, whereas 2 case-control studies focused on participants with non-fatal strokes ${ }^{41,52}$. Studies controlled for between 3 and 16 confounders in their analyses, presenting their outcomes as HRs RR or ORs ${ }^{18,30,31,39}$. Most studies reported results for all people with stroke, although some studies also presented subgroups or focused only on subgroups, which included type of stroke (e.g. ischemic, hemorrhagic), sex, age group, ethnic origin and risk factor (e.g. depression, hostility, disability). Of the 41 cohort studies included, 29 were of good methodological quality, 11 fair and 1 poor. Three case-control studies were of good methodological quality, 1 fair and 1 poor.

\section{Psychological Factors}

Twenty-seven cohort and three case-control studies examined the effects of psychological factors on the risk of stroke (Figure 2). Depression was the most common risk exposure, however stress, life satisfaction, and schizophrenia were reported in several studies, other factors included bipolar, panic disorder, morale, pessimism and sense of coherence. All except two cohort studies ${ }^{12,28}$ showed an increased risk of stroke among people with psychological risk factors. The pooled adjusted hazard ratio was 1.44 (95\% CI: 1.30; 1.59) with a high level of statistical heterogeneity $\left(\mathrm{I}^{2}=76 \%\right.$; $\left.<<0.00001\right)$. Exclusion of two cohort studies $^{24,28}$ that differed markedly reduced the pooled HR for the cohort studies presenting a 
HR or RR (HR 1.25; 95\% CI: 1.18; 1.33) and the overall meta-analysis (HR 1.39; 95\% CI: 1.27; 1.51). In doing so, it reduced the statistical heterogeneity among the cohort studies reporting HR or RR ( $\mathrm{I}^{2}$ declined from $67 \%$ to $26 \%$ ) and all studies pooled ( $\mathrm{I}^{2}$ declined from $76 \%$ to $67 \%)$. Exclusion of the cohort studies reporting a RR rather than $\mathrm{HR}^{16,33}$ had limited effect on the pooled estimate (HR 1.39, 95\% CI: 1.27; 1.52; $\mathrm{I}^{2}=68 \%, \mathrm{p}<0.00001$ ). Additional planned sensitivity analyses that excluded other outlying studies or that focused on the different types of risk estimate and/or study designs used (e.g. cohort studies reporting HR; case-control studies reporting OR) had limited effect on the pooled estimates.

\section{Vocational Factors}

Thirteen cohort studies considered the influence of vocational factors on the risk of stroke (Figure 3). Five studies included educational level as the risk exposure, others included social class, socioeconomic, job stain and poverty. Eleven cohort studies identified an increased risk of stroke among those with the vocational risk factor, with the other two cohort studies identifying differences between subgroups within their studies ${ }^{38,39}$. The pooled HR for the 13 studies was 1.35 (95\% CI: $1.20 ; 1.51)$, with significant statistical heterogeneity evident $\left(\mathrm{I}^{2}=\right.$ $60 \% ; \mathrm{p}<0.0004$ ) (Figure 3). A sensitivity analysis that excluded the two cohort studies with the subgroups had a limited effect on the pooled HR (HR 1.38; 95\% CI: 1.23; 1.54) or the statistical heterogeneity $\left(\mathrm{I}^{2}=57 \% ; \mathrm{p}=0.004\right)$.

\section{Behavioral Factors}

Two cohort studies assessed the effect of behavioral risk factors on stroke, ${ }^{18,43}$, reporting contradictory findings. Both studies included anger as the risk exposure. Although EversonRose et $\mathrm{al}^{18}$ found high levels of hostility associated with an increased risk of stroke, Eng et $\mathrm{al}^{43}$ reported that anger expression had a protective effect against subsequent strokes. The 
pooled HR was 0.94 (95\% CI: 0.20; 4.31) with a high level of heterogeneity $\left(\mathrm{I}^{2}=91 \%\right.$; $\mathrm{p}=0.0009$ ) (Figure 4).

\section{Interpersonal Factors}

Eight cohort studies and two case-control studies examined the effects of interpersonal factors on the risk of stroke (Figure 5). The most common risk exposure was social support, major life events, social burden and marital dissolution were also examined. Six cohort studies and a case-control study showed an increased risk of stroke for those with interpersonal risk factors. Two cohort studies and a case-control study identified an increased risk of stroke for those without the risk factor ${ }^{28,39,40}$, although for one cohort study ${ }^{39}$ and a subgroup of the case-control study ${ }^{40}$ the effect was marginal. The overall pooled HR was 1.16 (95\% CI: 1.03; 1.31), with a high degree of heterogeneity $\left(\mathrm{I}^{2}=74 \% ; \mathrm{p}=0.00001\right)$. The pooled HR for the cohort studies (HR 1.11, 95\% CI: 0.981.04; 1.26; $\mathrm{I}^{2}=65 \%$; $\mathrm{p}=0.003$ ) was more conservative than that for the case-control studies (HR 1.40, 95\% CI: 0.93; 2.13; $\mathrm{I}^{2}=87 \%$; $\mathrm{p}=0.0005$ ). Exclusion of a cohort study through sensitivity analysis ${ }^{28}$ whose outcome appeared to differ markedly from the other studies had limited effect on the overall pooled HR (1.17, 95\% CI: 1.04; 1.32; $\mathrm{I}^{2}=73 \%$; $\left.\mathrm{p}<0.0001\right)$. Further planned sensitivity analyses that assessed the effects of excluding studies reporting different types of outcome measure (i.e. HR or OR) had no significant effect on the overall pooled estimates.

Publication bias

Funnel plots for the meta-analysis of the effects of psychological risk factors on stroke appeared to be asymmetric, with both smaller studies and case-control studies presenting larger hazard ratios identifying a risk associated with psychological factors than from cohort studies and larger studies. The funnel plots for the meta-analyses of vocational and interpersonal risk factors showed a tendency for smaller studies to report larger effects both 
in term of a risk or no risk associated with the factor. As the funnel plot for studies assessing behavioral risk factors contained only two studies, no discernible pattern was evident.

\section{Suggested mechanisms}

The most frequently suggested mechanisms for the association between a psychosocial factor and stroke were related to lifestyle factors (table 3), including smoking, physical inactivity and alcohol intake. Lifestyle factors were suggested as a mechanism for psychological, vocational, and interpersonal processes. Physiological mechanisms were also repeatedly suggested for the association between psychosocial factors and stroke, particularly for the psychological and interpersonal categories. These were often suggested as indirect mechanisms, whereby a psychological factor, such as stress or depression, is associated with the activation of the hypothalamic-pituitary-adrenocortical axis, which can result in hypertension, endothelial dysfunction and platelet activation, which in turn increases risk of stroke. The suggested mechanisms for vocational factors (educational level and socioeconomic status) are mainly related to lifestyle factors and stress responses.

\section{Discussion}

The systematic review identified 46 studies, including 41 cohort studies and five cases control studies. The included studies were varied with regard to the description and exposure to the psychosocial risk factor. Of the 46 studies assessing the effects of the different psychosocial risk factors on the occurrence of stroke, 30 examined psychological factors, 12 vocational, 10 interpersonal and two behavioral risk factors. When meta-analysed, the forest plots and pooled estimates showed that all the different psychosocial risk factors were independent risk factors for stroke, except behavioural factors. Psychological factors were shown to increase the risk of stroke by $39 \%$, vocational by $35 \%$ and interpersonal by $16 \%$. Although behavioral factors were shown to have limited effect on the risk of stroke, this was based on only two studies and encompassed considerable uncertainty. The meta-analyses 
were affected by substantial heterogeneity $\left(\mathrm{I}^{2} \geq 60 \%\right)$.Sensitivity analyses, excluding heterogeneous studies and subgroup analyses pooling studies by study design and/or type of risk measure, suggested that risk estimates were robust. Despite this, the pooled HR should be interpreted with some caution as the extent of the risk remains uncertain. Funnel plots showed that the meta-analysis of psychological, vocational and interpersonal risk factors were affected by publication bias, whereas the plots for behavioral risk factors were less clear.

Consideration needs to be given to the cofounders. While we only included studies that adjusted for potential cofounders, some studies only adjusted for four, whereas others adjusted for 16. There was often a lack of information on important risk factors for stroke, such as hypertension, physical activity, atrial fibrillation, work-related factors or environment. Therefore, the results may also have been affected by other unadjusted or unmeasured risk factors; therefore caution is required when interpreting the results.

There is no accepted definition of a psychosocial risk factor. In this review we choose a broad definition, including psychological, vocational, behavioral and interpersonal factors. Our comprehensive approach has led to a wide variety of risk factors being included even within a classification. For example, the psychological category includes depression, stress, life satisfaction, bipolar disorder, schizophrenia, dispositional pessimism and panic attacks; however, the common component was psychological. Comparability between studies was restricted, as the measures of the psychosocial exposure also varied greatly, with less than half the studies measuring the exposure with a validated assessment tool. This was similar across all the different categories. This brings into question the validity of the psychosocial risk factor measurement. Furthermore, many of the studies did not undertake repeated measures, with some only measuring exposure at baseline; repeated measures may have given more reliable estimates of the risk factor and also stability of the risk factor over time. 
Psychosocial risk factors may induce or enhance a future stroke through a range of mechanisms. It is postulated that various psychosocial risk factors, such as depression, stress, anger and hostility, could trigger the sympathetic nervous system and the hypothalamicpituitary-adrenocortical axis, activating inflammatory pathways, which in turn increase Creactive protein (CRP), fibrinogen, raise homocysteine and cortisol levels and interleukin ${ }^{53,54}$; these inflammatory markers have been related to stroke risk ${ }^{55-57}$. Extended exposure to these psychosocial factors can result in hypertension and an increase in free fatty acids, causing damage to the lining of the blood vessels and thus increased susceptibility to atherosclerosis. By identifying and controlling stress and depression or increasing social support, it may be possible to reduce the intensity or duration of these neuroendocrine responses and thus reduce the risk of stroke.

However, evidence for an inflammatory pathway has not been supported in other studies where adjusting for these variables did not alter observed relationships ${ }^{18}$. Moreover, individual patient meta-analyses of some of these inflammatory markers such as CRP suggested that the association depended considerably on conventional risk factors and plasma fibrinogen ${ }^{56}$. Therefore, other deleterious factors such as smoking, poor diet, lack of exercise, obesity, poor adherence to treatment regimens, might increase the stroke risk. These lifestyle factors are associated with education level, poverty and job strain, as well as stress, depression and other mental health conditions. However, some studies that have controlled for these lifestyle factors have suggested that they are not a primary pathway through which stress and negative emotions contribute to subsequent stroke ${ }^{18}$. Thus the precise mechanisms underlying the link between psychosocial factors and stroke remain unclear. Both behavioral (lifestyle behaviors) and biological (autonomic nervous system activity) mechanisms are reasonable. Our findings suggest that identifying people with psychosocial risk factors may 
provide the opportunity to reduce the future burden of stroke through the timely implementation of preventative strategies.

\section{Limitations}

The systematic review has certain strengths and limitations. The review was undertaken following methods that were defined $a$ priori in a research protocol using recognized guidance $^{58}$. A limitation of the review was the nature of the risk factors used in the included studies. As many of the studies included a range of factors within the same categories, decisions were made as to which should be included, potentially influencing the outcome of the review. In addition, studies used different definitions or measures for similar risk factors, which may have influenced the estimates from the studies. The studies included were affected by substantial heterogeneity, evident through the characteristics of the included studies. The review and meta-analysis synthesised studies including: all people; men only or women only; age groups ranging from 18 to 100 years; all strokes, ischemic, haematological and TIAs; different follow-up periods from 1 day to 35 years; different risk measures (HRs, RRs and ORs) and study designs (cohort or case control) used; varying methodological quality; and different confounders within the analysis. In addition, the review was limited to English language studies and to evidence published after 2000.

\section{Conclusion}

Our results concur with other systematic reviews and meta-analyses that suggest psychosocial risk factors are moderately important risk factors for CVD. Given the limitations of the systematic review and meta-analyses, interpretation of the meta-analyses should be undertaken with some caution. It is evident that the different psychosocial factors do have an effect on the risk of stroke; however, the extent of the affect and whether this would be considered a significant clinical effect is less clear. 


\section{Acknowledgements/funding}

We acknowledge and thank Janet Reed for her support with the literature searches. Maree L Hackett is a recipient of a National Heart Foundation Future Leader Fellowship, Level 2 (100034, 2014-2017)

\section{Contribution of the author}

CEL, CW, KP, MLH and AC conceived the concept of the study and contributed to the design of the study. AC, CEL, JL, KP and HS screened the studies and CEL, JL, KP, HS, AC and MLH data extracted the literature. AC performed the data analysis, CEL, AC and KP drafted the manuscript and all authors undertook a critical read and approved the final manuscript 


\section{References}

1. World Health Organisation. The top 10 causes of death worldwide. 2017. Available at http://www.who.int/mediacentre/factsheets/fs310/en/. Accessed March 1, 2017

2. Neylon A, Canniffe C, Anand S, et al. A global perspective on psychosocial risk factors for cardiovascular disease. Prog Cardiovasc Dis 2013;55(6):574-81

3. Booth J, Connelly L, Lawrence M, et al. Evidence of perceived psychosocial stress as a risk factor for stroke in adults: a meta-analysis. BMC Neurology 2015;15:233

4. Dong JY, Zhang YH, Tong J, Qin LQ. Depression and risk of stroke: a meta-analysis of prospective studies. Stroke 2012;43(1):32-7

5. Ligthart SA, Richard E, Fransen NL, et al. Association of vascular factors with apathy in community-dwelling elderly individuals. Arch Gen Psychiatry 2012;69(6):636-642

6. Feller S, Teucher B, Kaaks R, Boeing H, Vigl M. Life Satisfaction and Risk of Chronic Diseases in the European Prospective Investigation into Cancer and Nutrition (EPIC)-Germany Study. PLoS ONE 2013;8(8):e73462

7. Salinas J, Beiser A, Himali JJ, et al. Associations between social relationship measures, serum brain-derived neurotrophic factor, and risk of stroke and dementia. Alzheimer's \& Dementia: Translational Research \& Clinical Interventions 2017;3(2):229-237

8. Rozanski A, Blumenthal JA, Kaplan J. Impact of psychological factors onteh pathogenesis of cardiovascular disease and implications for therapy. Circulation 1999;99(16):2192-2217 
9. NIH. Study quality assessment tools. 2014. Available at https://www.nhlbi.nih.gov/healthpro/guidelines/in-develop/cardiovascular-risk-reduction/tools. Accessed November 1, 2016

10. Higgins JPT, Green S (editors). Cochrane Handbook for Systematic Reviews of Interventions Version 5.1.0 [updated March 2011]. The Cochrane Collaboration, 2011. Available from www.handbook.cochrane.org.

11. Lahti M, Tiihonen J, Wildgust H, et al. Cardiovascular morbidity, mortality and pharmacotherapy in patients with schizophrenia. Psychological Medicine 2012;42:2275-2285

12. Salaycik KJ, Kelly-Hayes M, Beiser A, et al. Depressive Symptoms and Risk of Stroke: The Framingham Study. Stroke 2007;38:16-21

13. Andre-Petersson L, Engstrom G, Hedblad B, Janzon L, Rosvall M. Social support at work and the risk of myocardial infarction and stroke in women and men. Social Science \& Medicine 2007;64:830841

14. Arbelaez JJ, Ariyo AA, Crum RM, Fried LP, Ford DE. Depressive Symptoms, Inflammation, and Ischemic Stroke in Older Adults: A Prospective Analysis in the Cardiovascular Health Study. J Am Geriatr Soc 2007;55:1825-1830

15. Bos MJ, Linden T, Koudstaal PJ, et al. Depressive symptoms and risk of stroke: the Rotterdam Study. Neurol Neurosurg Psychiatry 2008;79:997-1001

16. Curkendall SM, Mo J, Glasser DB, Stang MR, Jones JK. Cardiovascular disease in patients with schizophrenia in Saskatchewan, Canada. J Clin Psychiatry 2004;65:715-720 
17. Eurelings LSM, Ligthart SA, van Dalen JW, van Charante EPM, van Gool WA, Richard E. Apathy is an independent risk factor for incident cardiovascular disease in the older individual: a population-based cohort study. Int J Geriatr Psychiatry 2014;29:454-463

18. Everson-Rose SA, Roetker NS, Lutsey PL, et al. Chronic Stress, Depressive Symptoms, Anger, Hostility, and Risk of Stroke and Transient Ischemic Attack in the Multi-Ethnic Study of Atherosclerosis. Stroke 2014;45:2318-2323

19. Gillum RF, Mussolino ME. Education, poverty, and stroke incidence in whites and blacks: The NHANES I Epidemiologic Follow-up Study. Journal of Clinical Epidemiology 2003;56:188-195

20. Hamano T, Li X, Lonn SL, et al. Depression, stroke and gender: evidence of a stronger association in men. J Neurol Neurosurg Psychiatry 2015;86:319-323

21. Honjo K, Iso H, Nakaya T, et al. Impact of Neighborhood Socioeconomic Conditions on the Risk of Stroke in Japan. J Epidemiol 2015;25(3):254-260

22. Ikeda A, Iso H, Kawachi I, Yamagishi K, Inoue M, Tsugane S. Social Support and Stroke and Coronary Heart Disease: The JPHC Study Cohorts II. Stroke 2008;39:768-775

23. Kornerup H, Osler M, Boysen G, Barefoot J, Schnohr P, Prescott E. Major life events increase the risk of stroke but not of myocardial infarction: results from the Copenhagen City Heart Study. Eur J Cardiovasc Prev Rehabil 2010;17(1):113-118

24. Lee H-C, Lin H-C, Tsai S-Y. Severely Depressed Young Patients Have Over Five Times Increased Risk for Stroke: A 5-Year Follow-Up Study. Biol Psychiatry 2008;64:912-915 
25. Li C, Hedblad B, Rosvall M, Buchwald F, Khan FA, Engstrom G. Stroke Incidence, Recurrence, and Case-Fatality in Relation to Socioeconomic Position: A Population-Based Study of Middle-Aged Swedish Men and Women. Stroke 2008;39:2191-2196

26. Lin H-C, Tsai S-Y, Lee H-C. Increased risk of developing stroke among patients with bipolar disorder after an acute mood episode: A six-year follow-up study. Journal of Affective Disorders 2007;100:49-54

27. McFadden E, Luben R, Wareham N, Bingham S, Khaw K. Social Class, Risk Factors, and Stroke Incidence in Men and Women: A Prospective Study in the European Prospective Investigation Into Cancer in Norfolk Cohort. Stroke 2009;40:1070-1077

28. Mejia-Lancheros C, Estruch R, Martinez-Gonzalez M, et al. Impact of psychosocial factors on cardiovascular morbimortality: a prospective cohort study. BMC Cardiovascular Disorders 2014, $14: 135$

29. Nabi H, Koskenvuo M, Singh-Manoux A, et al. Low Pessimism Protects Against Stroke: The Health and Social Support (HeSSup) Prospective Cohort Study. Stroke 2010;41:187-190

30. Nagayoshi M, Everson-Rose SA, Iso H, Mosley TH, Rose KM, Lutsey PL. Social Network, Social Support, and Risk of Incident Stroke: Atherosclerosis Risk in Communities Study. Stroke 2014;45:2868-2873

31. Nilsson FM, Kessing LV. Increased risk of developing stroke for patients with major affective disorder: A registry study. Eur Arch Psychiatry Clin Neurosci 2004;254:387-391 
32. Shirai K, Iso H, Ohira T, et al. Perceived Level of Life Enjoyment and Risks of Cardiovascular Disease Incidence and Mortality The Japan Public Health Center-Based Study. Circulation 2009;120:956-963

33. Surtees PG, Wainwright NWJ, Luben RL, Wareham NJ, Bingham SA, Khaw K-T. Adaptation to Social Adversity Is Associated With Stroke Incidence: Evidence From the EPIC-Norfolk Prospective Cohort Study. Stroke 2007;38:1447-1453

34. Surtees PG, Wainwright NWJ, Luben RL, Wareham NJ, Bingham SA, Khaw K-T. Psychological distress, major depressive disorder, and risk of stroke. Neurology 2008;70:788-794

35. Truelsen T, Nielsen N, Boysen G, Gronbaek M. Self-Reported Stress and Risk of Stroke: The Copenhagen City Heart Study. Stroke 2003;34:856-862

36. Tsai K-Y, Lee C-C, Chou Y-M, Su C-Y, Chou F H-C. The incidence and relative risk of stroke in patients with schizophrenia: A five-year follow-up study. Schizophrenia Research 2012;138:41-47

37. Tsutsumi A, Kayaba K, Ishikawa S. Impact of occupational stress on stroke across occupational classes and genders. Social Science \& Medicine 2011;72:1652e1658

38. Veronesi G, Ferrario MM, Chambless LE, et al. Gender differences in the association between education and the incidence of cardiovascular events in Northern Italy . European Journal of Public Health 2011;21(6):762-767

39. Yan T, Escarce JJ, Liang L-J, et al. Exploring psychosocial pathways between neighbourhood characteristics and stroke in older adults: the cardiovascular health study. Age and Ageing 2013;42:391-397 
40. Engstrom G, Khan FA, Zia E, et al. Marital dissolution is followed by an increased incidence of stroke. Cerebrovasc Dis 2004;18:318-324

41. O’Donnell MJ, Chin SL, Rangarajan S, et al. Global and regional effects of potentially modifiable risk factors associated with acute stroke in 32 countries (INTERSTROKE): a case-control study. Lancet 2016;388:761-75

42. Bergh C, Udumyan R, Fall K, Nilsagard Y, Appelros P, Montgomery S. Stress resilience in male adolescents and subsequent stroke risk: cohort study. J Neurol Neurosurg Psychiatry 2014;85:13311336

43. Eng PM, Fitzmaurice G, Kubzansky LD, Rimm EB, Kawachi I. Anger Expression and Risk of Stroke and Coronary Heart Disease Among Male Health Professionals. Psychosomatic Medicine 2003;65:100-110

44. Honjo K, Iso H, Inoue M, Tsugane S. Education, Social Roles, and the Risk of Cardiovascular Disease Among Middle-Aged Japanese Women: The JPHC Study Cohort I. Stroke 2008;39:28862890

45. Kuper H, Adami H-O, Theorell T, Weiderpass E. The Socioeconomic Gradient in the Incidence of Stroke: A Prospective Study in Middle-Aged Women in Sweden. Stroke 2007;38:27-33

46. Majed B, Arveiler D, Bingham A, et al. Depressive Symptoms, a Time-Dependent Risk Factor for Coronary Heart Disease and Stroke in Middle-Aged Men: The PRIME Study. Stroke 2012;43:17611767

47. May M, McCarron P, Stansfeld S, et al. Does Psychological Distress Predict the Risk of Ischemic Stroke and Transient Ischemic Attack? The Caerphilly Study. Stroke 2002;33:7-12 
48. Schiloer L, Soderberg M, Rosengren A, Jarvholm B, Toren K. Psychosocial work environment and risk of ischemic stroke and coronary heart disease: a prospective longitudinal study of 75236 construction workers. Scand J Work Environ Health 2015;41(3):280-287

49. Smoller JW, Pollack MH, Wassertheil-Smoller S, et al. Panic Attacks and Risk of Incident Cardiovascular Events Among Postmenopausal Women in the Women’s Health Initiative Observational Study. Arch Gen Psychiatry 2007;64(10):1153-1160

50. Araki A, Murotani Y, Kamimiya F, Ito H. Low Well-Being Is an Independent Predictor for Stroke in Elderly Patients with Diabetes Mellitus. J Am Geriatr Soc 2004;52:205-210

51. Riaz BK, Chowdhury SH, Karim MN, Feroz S, Selim S, Rahman MR. Risk factors of hemorrhagic and ischemic stroke among hospitalized patients in Bangladesh - A case control study. Bangladesh Med Res Counc Bull 2015;41:29-34

52. Egido JA, Castillo O, Roig B, et al. Is psycho-physical stress a risk factor for stroke? A casecontrol study. J Neurol Neurosurg Psychiatry 2012;83:1104-1110

53. Ranjit N, Diez-Roux AV, Shea S, et al. Psychosocial factors and inflammation in the multi-ethnic study of atherosclerosis. Arch Intern Med 2007;167:174-181

54. Ford DE, Erlinger TP. Depression and C-reactive protein in US adults: data from the Third National Health and Nutrition Examination Survey. Arch Intern Med 2004;164:1010-1014

55. Luna JM, Moon YP, Liu KM, et al. High-sensitivity C-reactive protein and interleukin-6dominant inflammation and ischemic stroke risk: the northern Manhattan study. Stroke 2014;45:979987 
56. The Emerging Risk Factors Collaboration. C-reactive protein concentration and risk of coronary heart disease, stroke, and mortality: an individual participant meta-analysis. The Lancet 2010;375(9709):132-140

57. Chuang SY, Bai CH, Chen WH, Lien LM, Pan WH. Fibrinogen independently predicts the development of ischemic stroke in a Taiwanese population: CVDFACTS study. Stroke 2009;40:15781584

58. Centre for Reviews and Dissemination. Systematic Reviews - CRD’s guidance for undertaking reviews in health care. 2009. Available at https://www.york.ac.uk/crd/guidance/. Accessed September 1,2016

59. Ohira T, Iso H, Satoh S, et al. Prospective Study of Depressive Symptoms and Risk of Stroke Among Japanese. Stroke 2001;32:903-908

60. Ohlin B, Nilsson PM, Nilsson J-A, Berglund G. Chronic psychosocial stress predicts long-term cardiovascular morbidity and mortality in middle-aged men. European Heart Journal 2004;25:867873

61. Jood K, Redfors P, Rosengren A, Blomstrand C, Jern C. Self-perceived psychological stress and ischemic stroke: a case-control study. BMC Medicine 2009;7:53 
Figure 1: Study selection flow diagram

Figure 2: Forest plot of overall pooled adjusted effect estimate for risk of stroke in subjects exposed to psychological factors

Figure 3: Forest plot of overall pooled adjusted effect estimate for risk of stroke in subjects exposed to vocational factors

Figure 4: Forest plot of overall pooled adjusted effect estimate for risk of stroke in subjects exposed to behavioral factors

Figure 5: Forest plot of overall pooled adjusted effect estimate for risk of stroke in subjects exposed to interpersonal factors 
Table 1: Characteristics of included cohort studies

\begin{tabular}{|c|c|c|c|c|c|c|c|c|c|}
\hline Author (year) & $\begin{array}{l}\text { Quality } \\
\text { rating }\end{array}$ & $\begin{array}{l}\text { Number of } \\
\text { participants } \\
\text { (\% male) }\end{array}$ & $\begin{array}{l}\text { Age at } \\
\text { baseline } \\
\text { (years) }\end{array}$ & $\begin{array}{l}\text { Risk factor exposure } \\
\text { and measure }\end{array}$ & $\begin{array}{l}\text { Duration } \\
\text { of follow } \\
\text { up (years) }\end{array}$ & $\begin{array}{l}\text { Number } \\
\text { of stroke } \\
\text { events }\end{array}$ & $\begin{array}{l}\text { Stroke } \\
\text { outcomes a }\end{array}$ & $\begin{array}{l}\text { Risk estimates } \\
(\mathrm{HR}(95 \% \mathrm{Cl}))\end{array}$ & $\begin{array}{l}\text { Number of } \\
\text { confounders controlled } \\
\text { for in adjusted model }\end{array}$ \\
\hline Psychological & & & & & & & & & \\
\hline Araki et al. $(2004)^{50}$ & Good & $305(33)$ & $>65$ & $\begin{array}{l}\text { Morale } \\
\text { PGC Morale Scale }\end{array}$ & 3 & 25 & & $2.70(1.10 ; 6.80)$ & 9 \\
\hline Arbelaez et al. $(2007)^{14}$ & Good & $5525(42)$ & $>65$ & $\begin{array}{l}\text { Depressive symptoms } \\
\text { Modified CES-D }\end{array}$ & 11 & 607 & $\begin{array}{l}\text { Ischemic } \\
\text { stroke only }\end{array}$ & $1.25(1.02 ; 1.53)$ & 15 \\
\hline Bergh et al. $(2014)^{40}$ & Good & $237879(100)$ & $31-35$ & $\begin{array}{l}\text { Stress resilience } \\
\text { Interview with psychologist }\end{array}$ & 13 & 3411 & & $1.16(1.04 ; 1.29)$ & 9 \\
\hline Bos et al. $(2008)^{13}$ & Good & $4394(40)$ & $\geq 55$ & $\begin{array}{l}\text { Depressive symptoms } \\
\text { CES-D and interview with } \\
\text { psychologist }\end{array}$ & 8 & 291 & & $1.21(0.80 ; 1.83)$ & 15 \\
\hline Curkendall et al. $(2004)^{14}$ & Good & $11580(50)$ & NR & $\begin{array}{l}\text { Schizophrenia } \\
\text { Clinical diagnosis }\end{array}$ & 4 & 241 & & $1.50(1.20 ; 2.00)$ & 5 \\
\hline Eurelings et al. (2014) ${ }^{17}$ & Fair & $1810(40)$ & $70-78$ & $\begin{array}{l}\text { Depression } \\
\text { GDS-15 }\end{array}$ & 2 & 55 & & $1.74(0.89 ; 3.38)$ & 5 \\
\hline Everson-Rose et al. (2014) & Good & $6749(47)$ & $45-84$ & Depression & 12 & 147 & & $1.73(1.08 ; 2.77$ & 16 \\
\hline
\end{tabular}




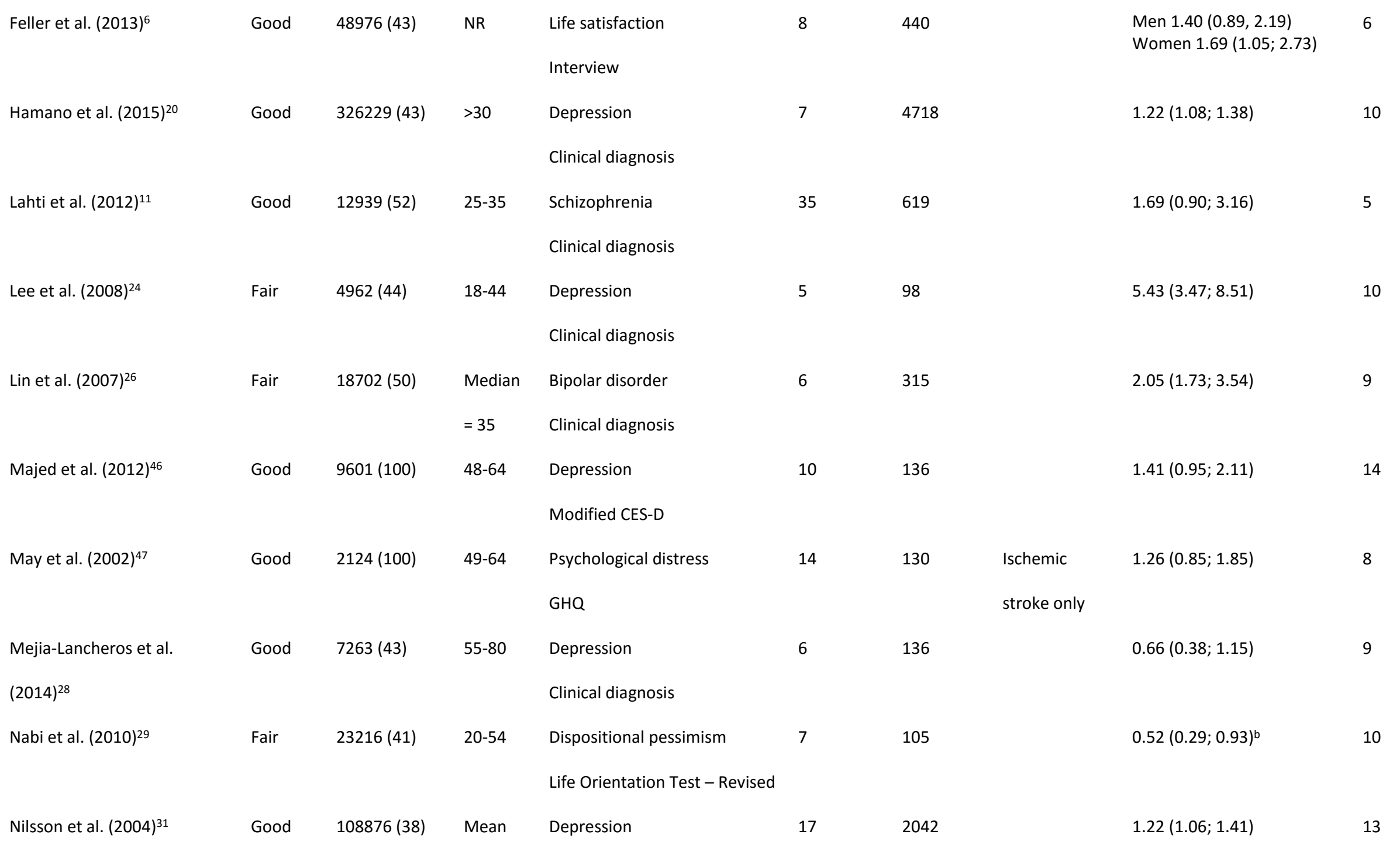




\begin{tabular}{|c|c|c|c|c|c|c|c|c|}
\hline & & & $=58$ & Clinical diagnosis & & & & \\
\hline \multirow[t]{2}{*}{ Ohira et al. $(2001)^{59}$} & Good & 879 (35) & $40-78$ & Depressive symptoms & 10 & 69 & $1.90(1.10 ; 3.50)$ & 9 \\
\hline & & & & SDS & & & & \\
\hline \multirow[t]{2}{*}{ Ohlin et al. (2004) } & Fair & $13280(80)$ & Mean & Chronic stress & 6 & 790 & $1.29(1.04 ; 1.60)$ & 11 \\
\hline & & & $=45$ & Questionnaire & & & & \\
\hline \multirow[t]{2}{*}{ Salaycik et al. $(2007)^{12}$} & Good & $4102(44)$ & $29-100$ & Depressive symptoms & 8 & 228 & $\begin{array}{l}<65 \text { yrs } 3.43(1.60 ; 7.36) \\
\geq 65 \text { yrs } 0.78(0.46 ; 1.34)\end{array}$ & 8 \\
\hline & & & & CES-D & & & & \\
\hline \multirow[t]{2}{*}{ Shirai et al. $(2009)^{32}$} & Fair & $88175(48)$ & $30-69$ & Life enjoyment & 12 & 2786 & Men $1.22(1.01 ; 1.47)$ & 11 \\
\hline & & & & Questionnaire & & & Women $1.09(0.86 ; 1.37)$ & \\
\hline \multirow[t]{2}{*}{ Smoller et al. $(2007)^{49}$} & Fair & $3243(0)$ & $51-83$ & Panic episodes & 7 & 40 & $1.98(0.75 ; 5.24)$ & 9 \\
\hline & & & & Questionnaire & & & & \\
\hline \multirow[t]{2}{*}{ Surtees et al. $(2007)^{33}$} & Good & $20629(43)$ & $41-80$ & Sense of coherence & 10 & 452 & $0.76(0.60 ; 0.96)^{b}$ & 13 \\
\hline & & & & HLEQ & & & & \\
\hline \multirow[t]{2}{*}{ Surtees et al. $(2008)^{34}$} & Good & $20627(43)$ & $41-80$ & Depression & 8.5 & 595 & $1.08(0.67 ; 1.75)$ & 13 \\
\hline & & & & HLEQ & & & & \\
\hline \multirow[t]{2}{*}{ Truelsen et al. $(2003)^{35}$} & Good & $12574(45)$ & $20-98$ & Stress & 17 & 929 & $1.13(0.85 ; 1.50)$ & 11 \\
\hline & & & & Questionnaire & & & & \\
\hline \multirow[t]{2}{*}{ Tsai et al. $(2012)^{36}$} & Good & $322276(55)$ & Mean & Schizophrenia & 10 & 4334 & $1.13(1.06 ; 1.22)$ & 8 \\
\hline & & & $=42.7$ & Clinical diagnosis & & & & \\
\hline
\end{tabular}




\section{Vocational}

\begin{tabular}{|c|c|c|c|c|c|c|}
\hline Gillum et al. $(2012)^{19}$ & Good & $5614(47)$ & $45-74$ & $\begin{array}{l}\text { Poverty } \\
\text { Total household income }\end{array}$ & 21 & 802 \\
\hline Honjo et al. $(2008)^{44}$ & Good & $20543(0)$ & $40-59$ & $\begin{array}{l}\text { Educational level } \\
\text { Questionnaire }\end{array}$ & 13 & 451 \\
\hline Honjo et al. $(2015)^{21}$ & Good & $90843(48)$ & $40-69$ & $\begin{array}{l}\text { Neighbourhood deprivation } \\
\text { Area Deprivation Index }\end{array}$ & 17 & 4410 \\
\hline Kuper et al. $(2007)^{45}$ & Good & $47942(0)$ & $30-49$ & $\begin{array}{l}\text { Educational level } \\
\text { Questionnaire }\end{array}$ & 11 & 200 \\
\hline Li et al. $(2008)^{25}$ & Good & $69625(49)$ & $40-65$ & $\begin{array}{l}\text { Socioeconomic status } \\
\text { Population register }\end{array}$ & 10 & 1648 \\
\hline McFadden et al. (2009)27 & Fair & 22488 (45) & $39-79$ & $\begin{array}{l}\text { Social class } \\
\text { Population register }\end{array}$ & 10 & 683 \\
\hline $\begin{array}{l}\text { Mejia-Lancheros et al. } \\
(2014)^{28}\end{array}$ & Good & $7263(43)$ & $55-80$ & $\begin{array}{l}\text { Educational level } \\
\text { Questionnaire }\end{array}$ & 6 & 136 \\
\hline
\end{tabular}

Black people 0.70 (0.46; $\quad 9$

1.08)*

White men 0.80 (0.57

1.12)*

White women 0.74 (0.52;

$1.05)^{*}$

$1.49(1.18 ; 1.89)$

$1.05(0.90 ; 1.23)$

$1.50(1.00 ; 2.20)$

Men 1.29 (1.06; 1.58)

Women 1.75 (1.36; 2.25)

$2.55(1.34 ; 4.85)$ 


\begin{tabular}{|c|c|c|c|c|c|c|c|c|c|}
\hline Schioler et al. $(2015)^{48}$ & Poor & $75326(100)$ & $\begin{array}{l}\text { Mean } \\
=36.8\end{array}$ & $\begin{array}{l}\text { Job strain } \\
\text { JDC }\end{array}$ & 15 & 739 & $\begin{array}{l}\text { Ischemic } \\
\text { stroke only }\end{array}$ & $1.13(0.95 ; 1.34)$ & 6 \\
\hline Tsai et al. $(2012)^{36}$ & Good & $322276(55)$ & $\begin{array}{l}\text { Mean } \\
=42.7\end{array}$ & $\begin{array}{l}\text { Socioeconomic status } \\
\text { Population register }\end{array}$ & 10 & 4334 & & $1.16(1.01 ; 1.33)$ & 8 \\
\hline Tsutsumi et al. $(2011)^{37}$ & Good & 6553 (49) & $18-65$ & $\begin{array}{l}\text { Job strain } \\
\text { JDC Japanese version }\end{array}$ & 13 & 147 & & $\begin{array}{l}\text { Men } 2.80(1.20 ; 6.40) \\
\text { Women } 1.30(0.60 ; 3.00)\end{array}$ & 6 \\
\hline Veronesi et al. $(2011)^{38}$ & Good & $5595(50)$ & $35-74$ & $\begin{array}{l}\text { Educational level } \\
\text { Questionnaire }\end{array}$ & 10 & 90 & $\begin{array}{l}\text { Ischemic } \\
\text { stroke only }\end{array}$ & $\begin{array}{l}\text { Men } 2.18(1.26 ; 3.78) \\
\text { Women } 0.40(0.20 ; 0.85)\end{array}$ & 6 \\
\hline Yan et al. $(2013)^{39}$ & Fair & $4619(41)$ & $\geq 65$ & $\begin{array}{l}\text { Educational level } \\
\text { Questionnaire }\end{array}$ & 14 & 652 & $\begin{array}{l}\text { Ischemic } \\
\text { stroke only }\end{array}$ & $\begin{array}{l}\text { White } 1.14(0.86 ; 1.52) \\
\text { African-American } 0.70 \\
(0.39 ; 1.28)\end{array}$ & 16 \\
\hline Behavioral & & & & & & & & & \\
\hline Eng et al. $(2003)^{43}$ & Fair & $23522(100)$ & $50-85$ & $\begin{array}{l}\text { Anger expression } \\
\text { Spielberger Anger-Out }\end{array}$ & 2 & 57 & & $0.42(0.20 ; 0.88)$ & 14 \\
\hline Everson-Rose et al. $(2014)^{18}$ & Good & 6749 (47) & $45-84$ & $\begin{array}{l}\text { Anger } \\
\text { Spielberger Trait Ange }\end{array}$ & 12 & 147 & & $2.00(1.15 ; 3.47)$ & 16 \\
\hline
\end{tabular}




\begin{tabular}{|c|c|c|c|c|c|c|c|c|c|}
\hline Andre-Petersson et al. & Good & $7770(61)$ & $45-64$ & Social support at work & 9 & 134 & & $1.80(1.05 ; 3.10)$ & 4 \\
\hline$(2007)^{13}$ & & & & Questionnaire & & & & & \\
\hline Araki et al. $(2004)^{50}$ & Good & $305(33)$ & $>65$ & $\begin{array}{l}\text { Social burden } \\
\text { EDBS }\end{array}$ & 3 & 25 & & $3.20(1.30 ; 7.80)$ & 9 \\
\hline Ikeda et al. $(2008)^{22}$ & Good & $44152(48)$ & $40-69$ & $\begin{array}{l}\text { Social support } \\
\text { Questionnaire }\end{array}$ & 11 & 1057 & & $1.11(0.89 ; 1.37)$ & 10 \\
\hline Kornerup et al. $(2010)^{23}$ & Good & $9542(43)$ & $\geq 20$ & $\begin{array}{l}\text { Major life events } \\
\text { Questionnaire }\end{array}$ & 10 & 350 & & $1.32(0.77 ; 2.25)$ & 10 \\
\hline Kuper et al. (2007) ${ }^{45}$ & Good & $47942(0)$ & $30-49$ & $\begin{array}{l}\text { Social support } \\
\text { Questionnaire }\end{array}$ & 11 & 200 & & $1.30(0.90 ; 1.80)$ & 7 \\
\hline $\begin{array}{l}\text { Mejia-Lancheros et al. } \\
(2014)^{28}\end{array}$ & Good & $7263(43)$ & $55-80$ & $\begin{array}{l}\text { Social support } \\
\text { Questionnaire }\end{array}$ & 6 & 136 & & $0.56(0.28 ; 1.12)$ & 9 \\
\hline Nagayoshi et al. (2014)30 & Fair & $13984(44)$ & $45-64$ & $\begin{array}{l}\text { Social support } \\
\text { LSNS, ISEL-SF }\end{array}$ & 23 & 905 & & $1.44(1.02 ; 2.04)$ & 16 \\
\hline Yan et al. $(2013)^{39}$ & Fair & $4619(41)$ & $\geq 65$ & $\begin{array}{l}\text { Social support } \\
\text { LSNS, ISEL-SF }\end{array}$ & 14 & 652 & $\begin{array}{l}\text { Ischemic } \\
\text { stroke only }\end{array}$ & $\begin{array}{l}\text { White } 1.02(0.98 ; 1.07) \\
\text { African-American } 1.02 \\
(0.93 ; 1.12)\end{array}$ & 16 \\
\hline
\end{tabular}

\footnotetext{
a Fatal and non-fatal stroke and all stroke types, unless otherwise stated
}

${ }^{\mathrm{b}}$ reciprocal 
Abbreviations: NR= not reported, PGC= Philadelphia Geriatric Centre, CES-D= Center for Epidemiologic Studies Depression Scale, GDS= Geriatric Depression Scale, GHQ= General Health

Questionnaire, SDS= Zung Self-Rating Depression Scale, HLEQ= Health and Life Experiences Questionnaire, JDC = Job Demand-Control Questionnaire, EDBS = Elderly Diabetes Burden Scale,

LSNS = Lubben Social Network Scale, ISEL-SF = Interpersonal Support Evaluation List-Short Form 
Table 2: Characteristics of included case-control studies

\begin{tabular}{|c|c|c|c|c|c|c|c|c|}
\hline Author (year) & $\begin{array}{l}\text { Quality } \\
\text { rating }\end{array}$ & $\begin{array}{l}\text { Number of } \\
\text { participants } \\
\text { cases:controls } \\
\text { (\% male) }\end{array}$ & Age (years) & $\begin{array}{l}\text { Cases:controls } \\
\text { with risk factor }\end{array}$ & $\begin{array}{l}\text { Risk factor exposure } \\
\text { and measure }\end{array}$ & $\begin{array}{l}\text { Stroke } \\
\text { outcomes }^{\text {a }}\end{array}$ & $\begin{array}{l}\text { Risk estimates } \\
(\mathrm{HR}(95 \% \mathrm{Cl}))\end{array}$ & $\begin{array}{l}\text { Number of } \\
\text { confounders } \\
\text { controlled for in } \\
\text { adjusted model }\end{array}$ \\
\hline Psychological & & & & & & & & \\
\hline Jood et al. $(2009)^{61}$ & Fair & $\begin{array}{l}\text { 600:600 } \\
(64)\end{array}$ & $18-69$ & $80: 29$ & $\begin{array}{l}\text { Stress } \\
\text { Questionnaire }\end{array}$ & $\begin{array}{l}\text { Ischemic } \\
\text { stroke only }\end{array}$ & $2.51(1.42 ; 4.44)$ & 11 \\
\hline O'Donnell et al. $(2016)^{41}$ & Good & $\begin{array}{l}13477: 13472 \\
(60)\end{array}$ & Mean $=62.2$ & $N R$ & $\begin{array}{l}\text { Psychosocial factors } \\
\text { Questionnaire }\end{array}$ & & $2.20(1.78 ; 2.72)$ & 10 \\
\hline Riaz et al. $(2015)^{51}$ & Poor & $\begin{array}{l}175: 171 \\
(73)\end{array}$ & $\begin{array}{l}\text { Mean stroke }=60.4 \\
\text { control }=63.7\end{array}$ & NR & $\begin{array}{l}\text { Psychosocial stress } \\
\text { Questionnaire }\end{array}$ & $\begin{array}{l}\text { Hemorrhagic } \\
\text { stroke only }\end{array}$ & $4.14(1.54 ; 11.09)$ & 13 \\
\hline Interpersonal & & & & & & & & \\
\hline Egido et al. $(2012)^{52}$ & Good & $\begin{array}{l}150: 300 \\
(77: 36)\end{array}$ & $18-65$ & $16: 9$ & $\begin{array}{l}\text { Life events } \\
\text { Holmes \& Rahe questionnaire }\end{array}$ & & $3.84(1.91 ; 7.70)$ & 8 \\
\hline Engstrom et al. $(2004)^{40}$ & Good & $\begin{array}{l}3134: 9402 \\
(45)\end{array}$ & $40-89$ & $\begin{array}{l}\text { Men 207:519 } \\
\text { Women 308:924 }\end{array}$ & $\begin{array}{l}\text { Marital dissolution } \\
\text { Population registers }\end{array}$ & & $\begin{array}{l}\text { Men } 1.23(1.03 ; 1.50) \\
\text { Women } 0.98(0.84 ; 1.20)\end{array}$ & 4 \\
\hline
\end{tabular}

a Fatal and non-fatal stroke and all stroke types, unless otherwise stated

Abbreviations: $\mathrm{NR}=$ not reported 
Table 3: The frequency of suggested mechanisms for psychosocial risk factors

\begin{tabular}{|c|c|c|}
\hline Suggested mechanism & Frequency & Psychosocial factor categories \\
\hline \multicolumn{3}{|l|}{ Physiological } \\
\hline Platelet activity & 8 & psychological, interpersonal processes \\
\hline Sympathetic nerve activity & 6 & psychological, interpersonal processes \\
\hline Blood coagulation & 2 & psychological \\
\hline Endothelial dysfunction & 4 & psychological, interpersonal processes \\
\hline HPA axis & 6 & psychological, interpersonal processes \\
\hline Inflammation & 8 & psychological, interpersonal processes \\
\hline Cortisol levels increase & 2 & psychological, interpersonal processes \\
\hline Heart rate variability abnormalities & 2 & psychological \\
\hline \multicolumn{3}{|l|}{ Co-morbid conditions } \\
\hline Hypertension & 5 & psychological, vocational \\
\hline Insulin resistance & 1 & psychological \\
\hline Diabetes & 2 & vocational \\
\hline Lipid abnormalities & 2 & Psychological, vocational \\
\hline \multicolumn{3}{|l|}{ Lifestyle } \\
\hline Diet & 4 & psychological, vocational, interpersonal processes \\
\hline Cigarette smoking & 12 & psychological, vocational, interpersonal processes \\
\hline Physical inactivity & 9 & psychological, vocational, interpersonal processes \\
\hline Alcohol intake & 4 & psychological, vocational, interpersonal processes \\
\hline Medication adherence & 4 & psychological, interpersonal processes \\
\hline Obesity & 4 & psychological, vocational \\
\hline Health screening & 3 & psychological, vocational \\
\hline \multicolumn{3}{|l|}{ Other } \\
\hline Vascular depression hypothesis & 1 & psychological \\
\hline Broaden and build theory & 1 & psychological \\
\hline Role enhancement theory & 1 & vocational \\
\hline Undernutrition in-utero & 1 & vocational \\
\hline Socioeconomic status & 1 & psychological \\
\hline Social interaction and support & 3 & psychological, vocational \\
\hline
\end{tabular}

